\title{
REAL ESTATE MANAGEMENT AS A SOURCE OF COMMUNE INCOME
}

\author{
Monika ŚPIEWAK-SZYJKA ${ }^{1}$, Milena BERA ${ }^{2}$, Aneta ZAREMBA ${ }^{3 *}$ \\ ${ }^{1}$ Wydział Ekonomiczny, Zachodniopomorski Uniwersytet Technologiczny w Szczecinie; monika.spiewak- \\ szyjka@zut.edu.pl, ORCID: 0000-0001-5527-0305 \\ ${ }^{2}$ Wydział Ekonomiczny, Zachodniopomorski Uniwersytet Technologiczny w Szczecinie; \\ milena.bera@zut.edu.pl, ORCID: 0000-0002-1997-349X \\ ${ }^{3}$ Wydział Ekonomiczny, Zachodniopomorski Uniwersytet Technologiczny w Szczecinie; \\ aneta.zaremba@zut.edu.pl, ORCID:0000-0002-5937-8548 \\ * Correspondence author
}

Introduction/background: Rational and effective management of public real estate is necessary for the proper functioning of this entity, as well as for the implementation of public tasks. Moreover, real estate stock is an important source of income. In order to find this out, it is necessary to analyze the state of a commune's real estate resources, focused on the implementation of specific goals such as: public investments and implementation of technical infrastructure devices.

Aim of the paper: The aim of this publication was to assess the role and significance of the share of income from real estate in the total income of the Szczecin City Commune; therefore, the research focused mainly on this income group. To fully illustrate the essence of the share of income from real estate, other sources of income of the audited entity are presented.

Materials and methods: A study of the measurement and evaluation of the phenomenon of changes over time was carried out on the basis of an analysis of the income dynamics of the Commune of Szczecin, with particular emphasis on the sources of income, as well as being broken down into budget classification sections. Moreover, in order to determine the changes taking place in the structure and level of the studied phenomenon over time, the dynamics indicators with a constant basis were calculated.

Results and conclusions: The conducted research has shown that real estate resources are an important source of income for the commune, and the most important of them is the real estate tax. The budget revenues from this source amounted on average to over PLN 240 million. In the years 2017-2019, the budgetary income of the commune had a growing tendency, and its value was, respectively: PLN 2,157 million, PLN 2,289 million and PLN 2,639 million.

The structure of the commune's income in the analyzed period shows a stable tendency and did not undergo major changes. The dominant item in the category of current income was the share in the income tax from natural persons and legal persons (share at an average level of approximately $28 \%$ ).

Keywords: communal real estate, income, expenses, Poland. 


\section{Introduction}

The proper functioning of local government units depends on their financing, by means of which a commune, a poviat or a voivodeship can implement specific public goals aimed at satisfying the needs of the local community. Income is managed within the budget. Distribution of income in many developed countries has increased dramatically in the last few decades (Leach et al., 2013). Rational and effective management of public real estate is necessary for the proper functioning of this entity, as well as for the implementation of public tasks. Moreover, real estate stock is an important source of income. In order to find this out, it is necessary to analyze the state of a commune's real estate resources, focused on the implementation of specific goals such as: public investments and implementation of technical infrastructure devices.

The aim of this publication was to assess the role and significance of the share of income from real estate in the total income of the Szczecin City Commune; therefore, the research focused mainly on this income group. To fully illustrate the essence of the share of income from real estate, other sources of income of the audited entity are presented. The time spectrum of the conducted analyses covers the years 2017-2019. For the empirical part of the work, data from the publications of the Central Statistical Office was used. Moreover, the research was supported by a case study analysis and the financial statements of the Szczecin City Commune.

The study of measurement and evaluation of the phenomenon of changes over time was carried out on the basis of an analysis of the income dynamics of the Szczecin City Commune, with particular emphasis on the sources of income, as well as being broken down into budget classification sections. Moreover, in order to determine the changes taking place in the structure and level of the examined phenomenon over time, the dynamics indicators with a constant basis were calculated.

Due to its size, real estate owned by communes is an important segment of the real estate market (Marona, Van den Beemt-Tjeerdsma, 2018).

There have been many attempts in literature to define the term real estate management. According to Wisniewski, real estate management is a set of connections between entities and the subject of management (Wisniewski, 2008). The subjects in relation to real estate management are those who have rights to the real estate. The objects, on the other hand, are real estate and the rights associated with it (Cymerman, Filipiak-Kowszyk, 2015). Źróbek defines real estate management as a set of activities considered as standard activities, behaviors and goals resulting from the provisions regulating certain forms of real estate management aimed at rational use and management (Źróbek, 2004).

Literature also defines real estate management as 'a set of relations and procedures between entities and the object of management'. The 'set' relates to real estate, as well as the rights associated with it (rights in rem, limited rights in rem). The entity is considered to be the persons 
having rights to the real estate, while the subject is real estate and the rights related to it. The activities of real estate management include: real estate appraisal, inventory of stock, preparation of geodetic and legal studies, purchase and sale of real estate, carrying out mergers and divisions.

Communal real estate management is obligatory, and its conduct is provided for by statutes. The economy is implemented with the use of instruments: strategic, operational, administrative and financial. Strategic instruments are responsible for the commune's development strategy and for the preparation of studies of the conditions and directions of spatial development. Operational instruments include the preparation of local spatial development plans and the issuing of decisions on building conditions and land development. Administrative and financial instruments include: sale, exchange, lending, rental, handing over into permanent management, real estate divisions, planning fees and related fees. These instruments are considered one group due to the fact that most of them are dual in nature (Kokot, 2018).

As part of real estate management, resources can be increased or decreased by the situations occurring between public administration entities, which are:

- sale (it is possible to lower the price in relation to the market value of the property, which is the subject of negotiations between the parties),

- donation (for the public good),

- exchange,

- free perpetual usufruct (land of local government units for the benefit of the State Treasury and vice versa),

- permanent management,

- encumbering real estate with limited material rights,

- making real estate contributions in kind to companies,

- waiver (local government units to the State Treasury and vice versa),

- acquisition (for the construction of motorways - acquired by Highway Construction Agency for the State Treasury),

- expropriation (only real estate of local government units for the benefit of the State Treasury).

The real estate resources of a commune include real estate owned by the commune (except for perpetual usufruct rights) and real estate for which the commune is a perpetual usufruct user. A representative of the commune in the field of real estate management, i.e. the head of the commune, mayor or city president, is responsible for the management of these resources. 


\section{Research methodology}

The commune, as a public entity, is obliged to carry out the tasks incumbent on it; therefore, the entity must have adequate sources of income to be able to carry out these tasks (Hanusz et al., 2006). To fully illustrate the essence of the share of income from real estate, other sources of income of the examined entity are presented. The time spectrum of the conducted analyses covers the years 2017-2019. For the empirical part of the study, data from CSO publications was used. Moreover, the study was supported by a case study analysis and the financial statements of the Szczecin City Commune. A study of measurement and evaluation of the phenomenon of changes in time was carried out based on an analysis of the income dynamics of the Szczecin City Commune, with particular emphasis on the sources of income, as well as division into budget classification sections. Moreover, in order to determine the changes taking place in the structure and level of the examined phenomenon over time, constant dynamics indicators were calculated.

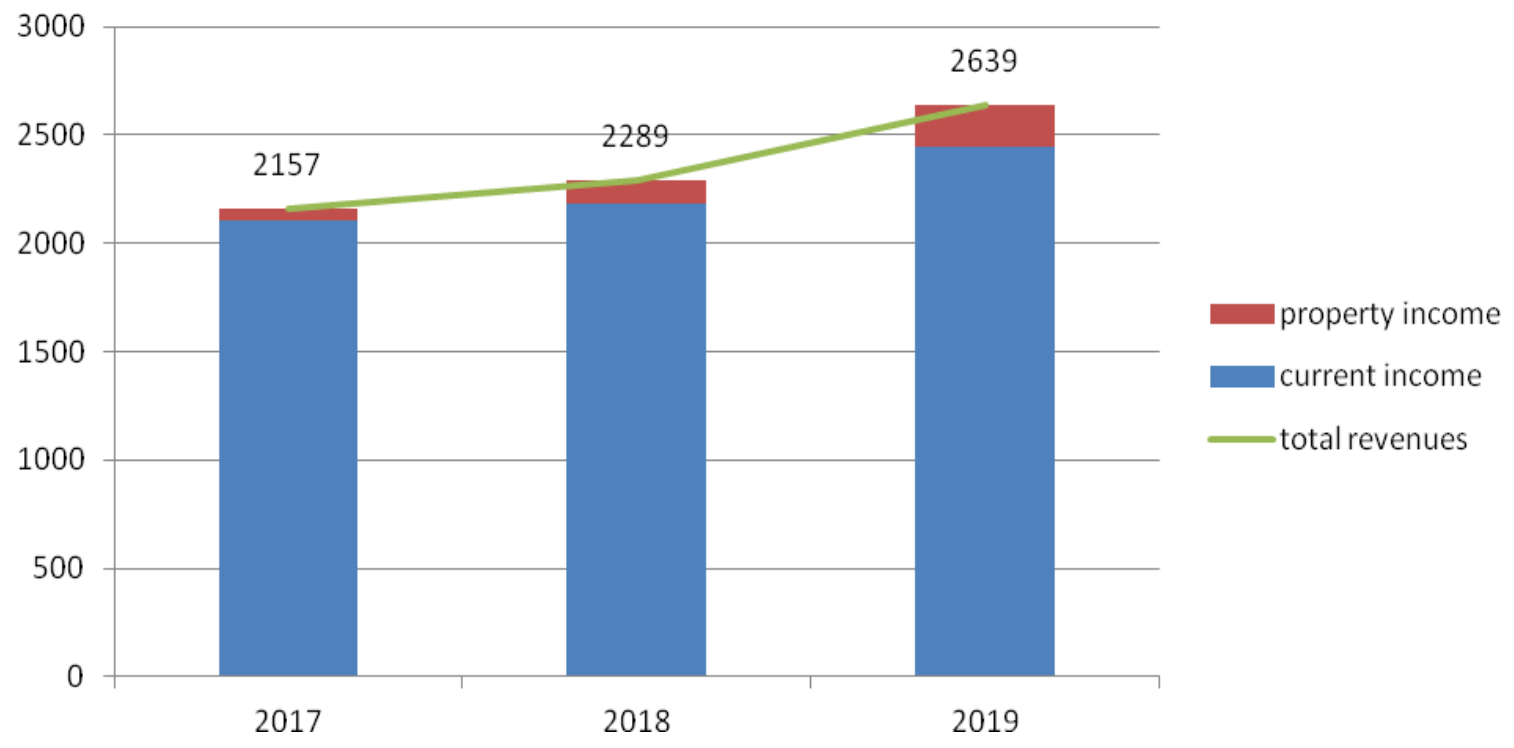

Figure 1. Income of the Szczecin City Commune in the years 2017-2019 (PLN million). Adapted from: Reports on budget execution for 2017, 2018, 2019 published at http://bip.um.szczecin.pl/ (access date 15.04.2020).

The data in Figure 1 presents the income of the analyzed local government unit divided into current and property income. In the analyzed period, the structure does not change, which means that current income is the key issue. The income of the analyzed entity shows an upward trend both in total income and in the division into current and property income. The income of the City of Szczecin in 2019 amounted to PLN 2,639 million, which is an increase of over PLN 400 million compared to the previous year. 


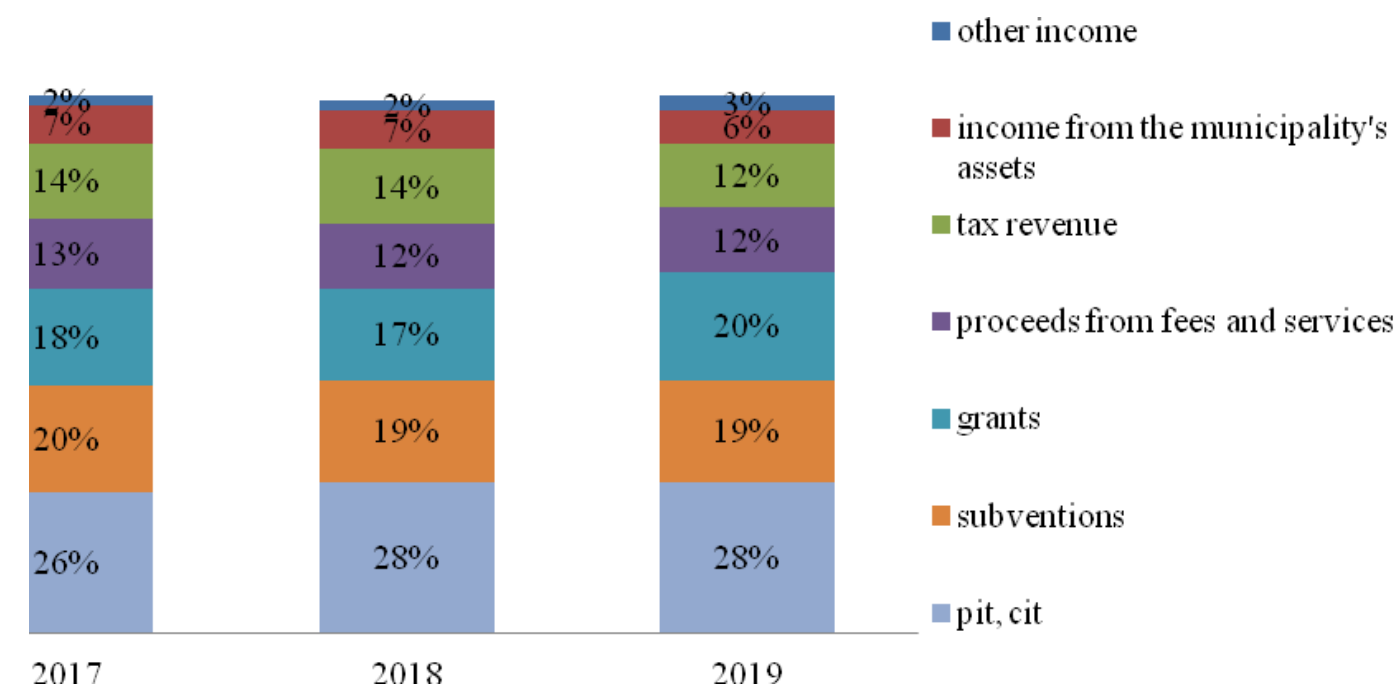

Figure 2. Share of particular current income items in the Szczecin City Commune in 2017-2019. Adapted from: Reports on budget execution for 2017, 2018, 2019 published on http://bip.um.szczecin.pl/ (accessed: 15.04.2020).

The structure of current income in 2017-2019 (Figure 2) in the analyzed entity did not change. Income from participation in personal income tax (PIT) and corporate income tax (CIT) was the most profitable group and accounted for approximately $28 \%$ of current income. Moreover, a systematic increase in the share of funds coming from EU subsidies can be observed. An important issue in budgeting is the division of income into own income and extraordinary income (Table 1). The former is granted by law for an indefinite period of time and comes from the municipality's own activities, while the latter is not of a permanent nature, such as funds from the European Union budget, funds from the sale of securities and funds from the sale of securities from the privatization of the assets of a local government unit, funds from loans and credits received (Public Finance Act of 27 August 2009).

\section{Table 1.}

Income structure of the Szczecin City Commume in 2017-2019 (in PLN million)

\begin{tabular}{|l|l|l|l|}
\hline \multicolumn{1}{|c|}{ Source of income } & \multicolumn{1}{c|}{$\mathbf{2 0 1 7}$} & \multicolumn{1}{c|}{$\mathbf{2 0 1 9}$} \\
\hline 1. Own income & $1,296.60$ & $1,373.00$ & $1,482.01$ \\
\hline - tax & 840.70 & 924.50 & 984.11 \\
\hline - non-tax & 455.90 & 448.50 & 497.89 \\
\hline 2. Subsidies & 419.50 & 431.30 & 471.69 \\
\hline 3. Subsidy & 387.70 & 381.60 & 494.15 \\
\hline 4. Others & 53.00 & 102.90 & 191.00 \\
\hline Sum & $2,156.80$ & $2,288.80$ & $2,638.85$ \\
\hline
\end{tabular}

Adapted from: Reports on budget implementation for 2017, 2018, 2019 published at http://bip.um.szczecin.pl/ (accessed: 15/04/2020).

The structure of revenue may also be broken down by budget classification heading. Budgetary classification systematizes public funds and is applied to all public sector entities. The practical role of budget classification can be briefly described in such a way that, thanks to the divisional system, budget classification is a convenient instrument for describing public funds used for the purposes of planning and financial (accounting) records and financial 
statements and facilitates statistical research on the public funds raised and their disposal for public purposes (Lachiewicz, 2016). The revenues of the city of Szczecin City Commune by budget classification headings in 2017-2019 are presented in Table 2.

Table 2.

Income of the Szczecin City Commune by budget classification divisions in the years 2017-2019 (in PLN thousand)

\begin{tabular}{|c|c|c|c|c|c|c|c|c|}
\hline $\begin{array}{c}\text { Budget } \\
\text { classification }\end{array}$ & 2017 & 2018 & 2019 & $\begin{array}{l}\text { dynamics } \\
2018 / 2017 \\
\end{array}$ & $\begin{array}{l}\text { dynamics } \\
2019 / 2018 \\
\end{array}$ & $\begin{array}{c}\text { share } \\
2017 \\
\end{array}$ & $\begin{array}{c}\text { share } \\
2018 \\
\end{array}$ & $\begin{array}{c}\text { share } \\
2019 \\
\end{array}$ \\
\hline $\begin{array}{l}\text { agriculture and } \\
\text { hunting }\end{array}$ & 25.97 & 26.57 & 27.53 & 1.02 & 1.04 & $0.001 \%$ & $0.001 \%$ & $0.001 \%$ \\
\hline forestry & 454.91 & 220.36 & 164.32 & 0.48 & 0.75 & $0,02 \%$ & $0.01 \%$ & $0.01 \%$ \\
\hline $\begin{array}{l}\text { electricity, gas } \\
\text { and water } \\
\text { generation }\end{array}$ & $9,026.64$ & $10,029.61$ & $9,193.80$ & 1.11 & 0.92 & $0,42 \%$ & $0.44 \%$ & $0.35 \%$ \\
\hline $\begin{array}{l}\text { transport and } \\
\text { communication }\end{array}$ & $125,237.65$ & $154,807.01$ & $232,825.77$ & 1.24 & 1.50 & $5.81 \%$ & $6.76 \%$ & $8.82 \%$ \\
\hline tourism & - & 7.11 & 519.55 & - & 73.11 & - & $0.0003 \%$ & $0.02 \%$ \\
\hline $\begin{array}{l}\text { housing } \\
\text { economy }\end{array}$ & $182,674.62$ & $184,206.29$ & $192,703.93$ & 1.01 & 1.05 & $8.47 \%$ & $8.05 \%$ & $7.30 \%$ \\
\hline service activities & $13,077.46$ & $13,994.60$ & $15,439.92$ & 1.07 & 1.10 & $0.61 \%$ & $0.61 \%$ & $0.59 \%$ \\
\hline $\begin{array}{l}\text { public } \\
\text { administration }\end{array}$ & $7,874.46$ & $7,813.71$ & $17,827.44$ & 0.99 & 2.28 & $0.37 \%$ & $0.34 \%$ & $0.68 \%$ \\
\hline offices & 86.14 & $2,185.74$ & $2,264.50$ & 25.37 & 1.04 & $0.004 \%$ & $0.10 \%$ & $0.09 \%$ \\
\hline public safety & $23,676.26$ & $25,071.42$ & $28,583.65$ & 1.06 & 1.14 & $1.10 \%$ & $1.10 \%$ & $1.08 \%$ \\
\hline justice & 967.68 & 961.42 & $1,054.71$ & 0.99 & 1.10 & $0.04 \%$ & $0.04 \%$ & $0.04 \%$ \\
\hline $\begin{array}{l}\text { income from } \\
\text { legal persons, } \\
\text { natural persons } \\
\text { and other units } \\
\text { without legal } \\
\text { personality }\end{array}$ & $903,400.92$ & $985,511.17$ & $\begin{array}{l}1,049 \\
049,03\end{array}$ & 1.09 & 1.06 & $41.89 \%$ & $43.06 \%$ & $39.75 \%$ \\
\hline $\begin{array}{l}\text { public debt } \\
\text { service }\end{array}$ & - & - & - & - & - & - & - & - \\
\hline $\begin{array}{l}\text { various } \\
\text { settlements }\end{array}$ & $425,951.32$ & $434,879.63$ & $475,605.77$ & 1.02 & 1.09 & $19.75 \%$ & $19.00 \%$ & $18.02 \%$ \\
\hline $\begin{array}{l}\text { education and } \\
\text { upbringing }\end{array}$ & $31,151.82$ & $26,901.92$ & $30,238.52$ & 0.86 & 1.12 & $1.44 \%$ & $1.18 \%$ & $1.15 \%$ \\
\hline higher education & - & - & - & - & - & - & - & - \\
\hline healthcare & $6,048.21$ & $4,486.96$ & $4,179.34$ & 0.74 & 0.93 & $0.28 \%$ & $0.20 \%$ & $0.16 \%$ \\
\hline social assistance & $49,411.76$ & $48,843.92$ & $49,379.46$ & 0.99 & 1.01 & $2.29 \%$ & $2.13 \%$ & $1.87 \%$ \\
\hline social policy & $5,706.80$ & $10,238.14$ & $18,977.14$ & 1.79 & 1.85 & $0.26 \%$ & $0.45 \%$ & $0.72 \%$ \\
\hline $\begin{array}{l}\text { educational } \\
\text { childcare }\end{array}$ & $3,251.59$ & $2,290.38$ & $1,954.16$ & 0.70 & 0.85 & $0.15 \%$ & $0.10 \%$ & $0.07 \%$ \\
\hline family & $268,893.81$ & $276,937.40$ & $381,583.49$ & 1.03 & 1.38 & $12.47 \%$ & $12.10 \%$ & $14.46 \%$ \\
\hline $\begin{array}{l}\text { municipal } \\
\text { economy }\end{array}$ & $78,720.32$ & $86,228.95$ & $107,302.33$ & 1.10 & 1.24 & $3.65 \%$ & $3.77 \%$ & $4.07 \%$ \\
\hline culture & 940.28 & $1,263.64$ & $1,539.08$ & 1.34 & 1.22 & $0.04 \%$ & $0.06 \%$ & $0.06 \%$ \\
\hline physical culture & $20,227.05$ & $11,912.33$ & $18,433.44$ & 0.59 & 1.55 & $0.94 \%$ & $0.52 \%$ & $0.70 \%$ \\
\hline SUM & $\begin{array}{c}2 \\
156,805.67\end{array}$ & $\begin{array}{c}2,288,818.2 \\
6\end{array}$ & $\begin{array}{l}2,638 \\
846.86\end{array}$ & 1.06 & 1.15 & $100.00 \%$ & $100.00 \%$ & $100.00 \%$ \\
\hline
\end{tabular}

Adapted from: Reports on budget implementation for 2017, 2018, 2019 published at http://bip.um.szczecin.pl/ (accessed: 15/04/2020). 
In the years 2017-2019, the most significant share in the municipality's income according to the budget classification sections was income from legal persons, natural persons and other entities without legal personality and constituted on average as much as $41.6 \%$ of the total income. The value of funds from this department in the period under review was in the range of PLN 900,000-1,050,000. The growth rate of this income group was 1.09 and 1.06, respectively. The income from this section includes the following:

- fines and penalties,

- adiacent fee

- communication fee

- license fee,

- charge on possession of dogs,

- stamp duty,

- trade fair fee,

- parking fee,

- fee for entry in the register of crèches,

- fee for issuing a driving license,

- fee for issuing a license to sell alcohol,

- lane occupancy charge,

- income tax in the form of a tax card,

- tax on civil law transactions,

- property tax,

- inheritance and donation tax,

- agricultural and forestry tax,

- tax on means of transport,

- shares in personal and corporate income tax.

The heading of the budget classification with income having a declining tendency was health care, and the growth rate was at 0.74 and 0.93 , and the share of this group in total income was only $0.21 \%$ on average.

\section{Results and discussion}

The commune's income from real estate, which has been mentioned earlier, is income derived from:

- lease and rental of property components,

- occupation of land for technical infrastructure,

- perpetual usufruct fees,

- fees for transforming the right of perpetual usufruct into the right of ownership, 
- fees for land easements and transmission,

- fees for permanent management,

- real estate tax,

- agricultural and forest tax,

- adiacent fee,

- sale of land, buildings, premises and apartments.

Table 3 presents the amount of individual incomes of the Szczecin City Commune from real estate.

Table 3.

Income from real estate in the Szczecin City Commune in 2017-2019 (in PLN thousand).

\begin{tabular}{|c|c|c|c|}
\hline Income & 2017 & 2018 & 2019 \\
\hline Lease and rental of assets & $88,272,395$ & $91,071,696$ & $88,729,395$ \\
\hline Income from taking land for technical infrastructure & 639,666 & 738,760 & $1,068,227$ \\
\hline Land for perpetual usufruct & $329,165.00$ & $383,698.00$ & $2,418,787$ \\
\hline Fee for perpetual usufruct & $31,957.469$ & $31,279.809$ & $24,097.593$ \\
\hline Transformation of the right of perpetual usufruct into ownership & $2,382,257$ & $1,741,914$ & $9,273,734$ \\
\hline Fee for ground and transmission easements & $1,890,808$ & $1,568,557$ & $1,578,233$ \\
\hline Fee for permanent management & $2,346,665$ & $2,335,997$ & $2,461,594$ \\
\hline Real estate tax & $236,490,130$ & $249,723,123$ & $247,408,891$ \\
\hline Agricultural tax & 275,634 & 264,126 & 237,303 \\
\hline Forest tax & 207,064 & 213,597 & 207,977 \\
\hline Adiacent fee & 194,466 & 286,340 & 466,380 \\
\hline Sale of buildings and commercial premises & $1,284,587$ & $1,138,219$ & $2,274,983$ \\
\hline Ownership of land & $15,898,165$ & $14,196,732$ & $22,706,317$ \\
\hline Sale of developed real estate & 602,401 & 0 & 0 \\
\hline Sale of apartments & $8,802,833$ & $10,756,991$ & $9,911,693$ \\
\hline Acquisition of real estate by inheritance & 440,913 & 393,409 & 328,857 \\
\hline Other property income & $6,369,512$ & $5,421,117$ & $5,547,258$ \\
\hline SUM & $398,384,130$ & $411,514,085$ & $418,717,222$ \\
\hline
\end{tabular}

Total real estate income in the period under review showed an upward trend and amounted to PLN 398 million, PLN 411 million and PLN 419 million, respectively, which represented on average $17.44 \%$ of the total income of the analyzed entity. The item from which about $60 \%$ of the income from real estate comes is real estate tax. In the years 2017-2019, in the Szczecin City Commune the value of revenue from this item amounted on average to PLN 244,540,715. The second significant item was income from the lease of property components. The income here in 2017-2019 amounted to: PLN 88,272,395, PLN 91,071,696 and PLN 88,729,395, which was an average share of $21.5 \%$.

Figures 3-5 present the structure of income from real estate in the Szczecin City Commune in 2017-2019. 


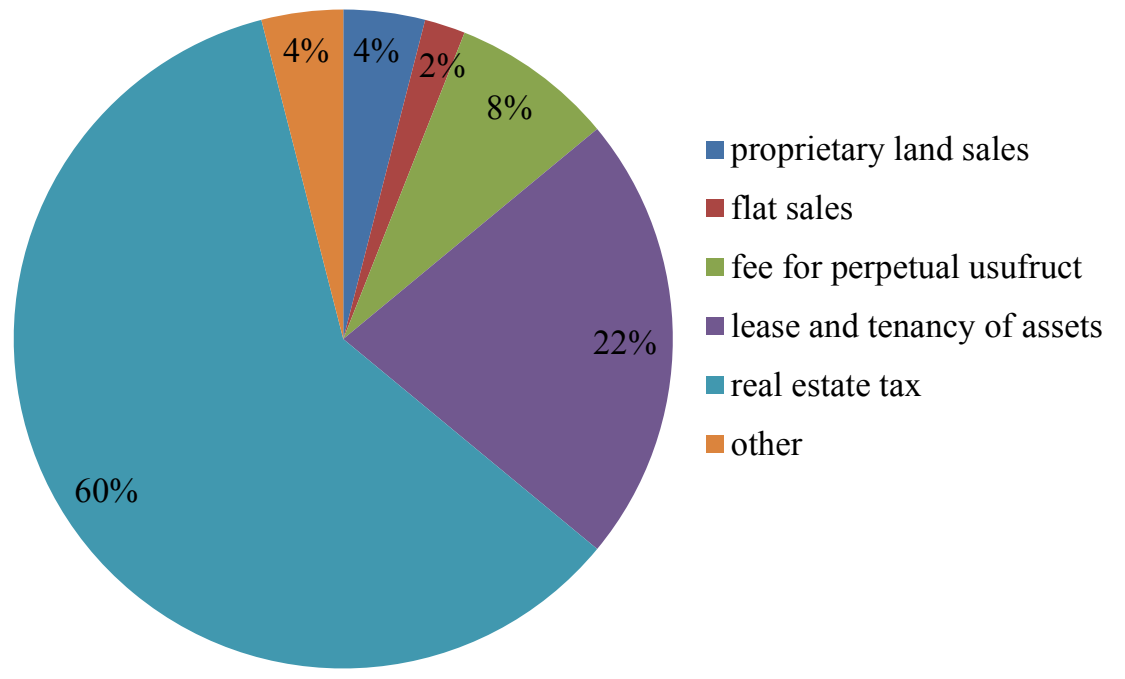

Figure 3. Structure of property income in the Szczecin City Commune in 2017. Adapted from: Own elaboration based on reports on budget execution for 2017, 2018, 2019 published on http://bip.um.szczecin.pl/ (accessed: 11.05.2020).

The dominant income in the structure of income from real estate in the Szczecin City Commune in 2017 was that obtained from property tax. It constituted $60 \%$ of the income in this category. Significant income was also obtained from lease and tenancy of assets belonging to the audited entity, the share of which was $22 \%$. Income from perpetual usufruct fees in 2017 accounted for $8 \%$ of total property income. The share of other income from real estate was not significant.

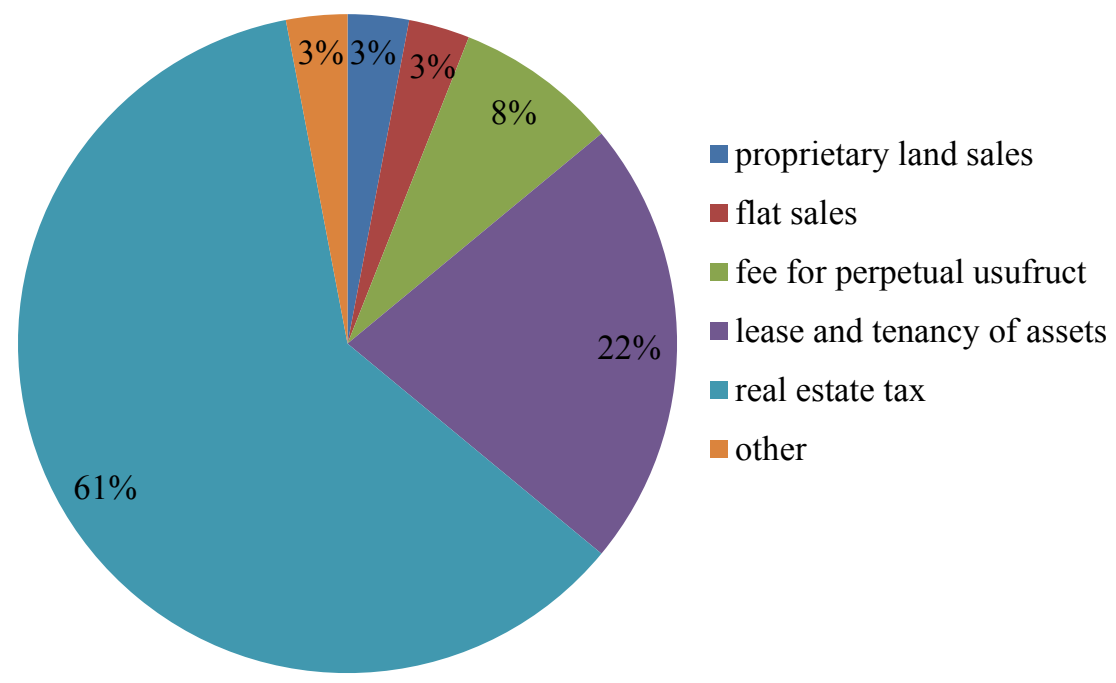

Figure 4. Structure of property income in the Szczecin City Commune in 2018. Source: Own elaboration based on reports on budget execution for 2017, 2018, 2019 published on http://bip.um.szczecin.pl/ (accessed: 11.05.2020).

The income structure in 2018 compared to 2017 was very similar. The differences that can be observed include an increase in the share of income from property tax and income from the sale of flats by one percentage point. 


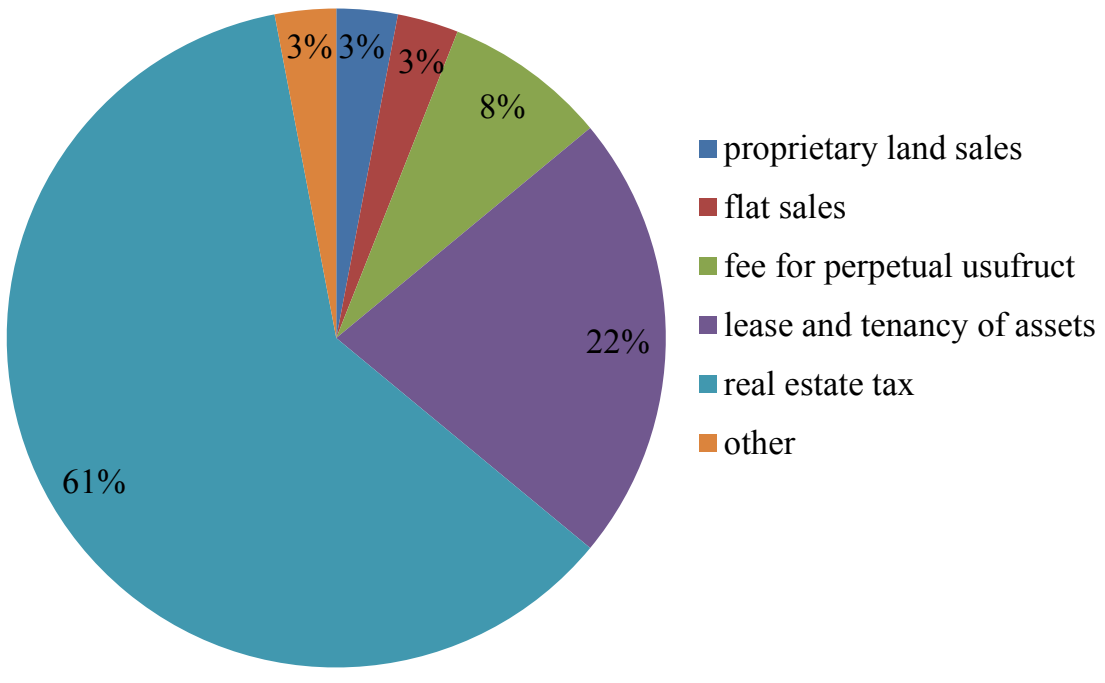

Figure 5. Structure of property income in the Szczecin City Commune in 2019. Source: Own elaboration based on reports on budget execution for 2017, 2018, 2019 published on http://bip.um.szczecin.pl/ (accessed: 11.05.2020).

Real estate tax is the local tax of municipalities. The following real estate or construction objects are subject to real estate tax: land, buildings or their parts and structures or their parts related to running a business (Oclesa, 2016). In 2019, the income from real estate tax dominated the structure of income from real estate in the Szczecin City Commune similarly to previous years. The second most profitable item was income from lease and tenancy of assets.

The structure in the analyzed period did not change much. Throughout the entire period, the dominant items were revenues from real estate tax and income from lease and tenancy of assets. Less profitable items are: perpetual usufruct fee, sale of apartments and land.

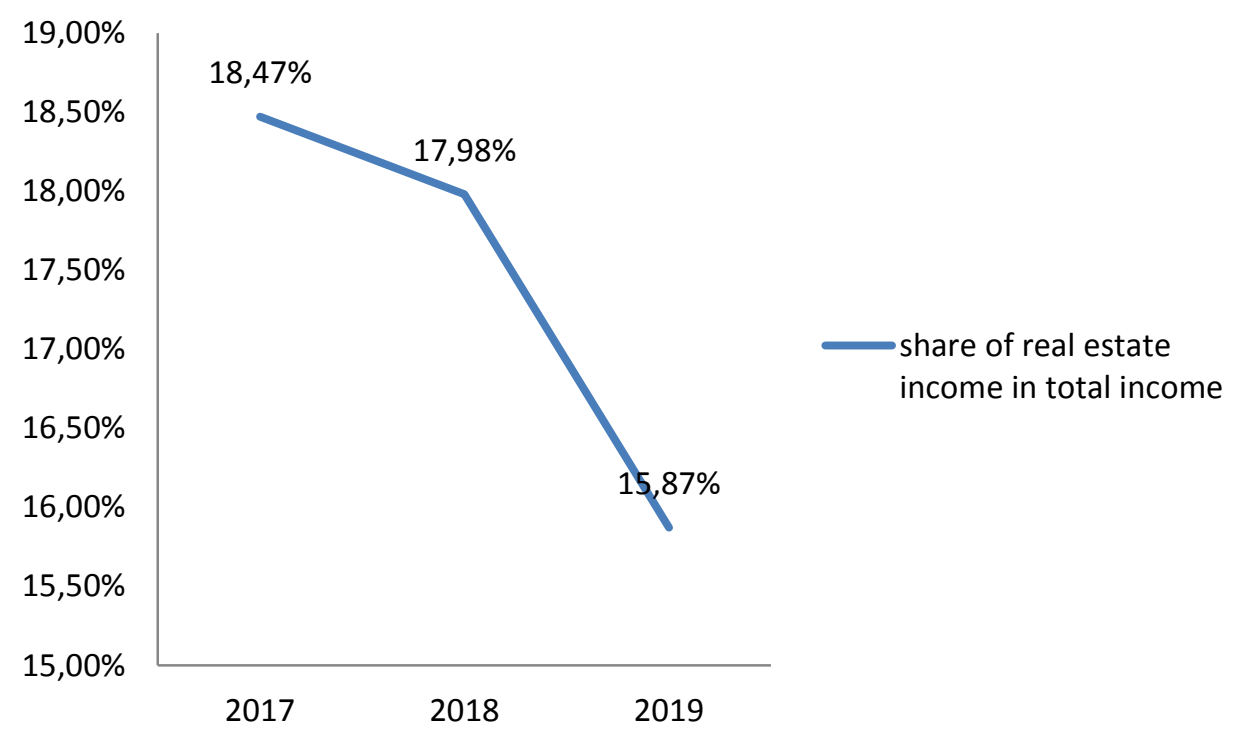

Figure 6. Share of real estate income in total income between 2017 and 2019. Source: Own elaboration based on reports on budget execution for 2017, 2018, 2019 published on http://bip.um.szczecin.pl/ (accessed: 11.05.2020). 
The sum of income from real estate in 2017-2019 in the Szczecin City Commune amounted to PLN 398 million, PLN 412 million and PLN 419 million, respectively. Despite the growing tendency of these values, the share in total income decreased. In 2017, the share of real estate income was $18.47 \%$, in $201817.98 \%$, while in 2019 , this share was $15.87 \%$.

\section{Conclusion}

Ownership of real estate is one of the attributes of the independence of communes, and the most important role in own income is the income from property, with the amount and structure of this income largely dependent on communal property resources. With the help of real estate resources, the commune can carry out the public tasks assigned to it; moreover, it is a significant source of its own income. Based on the research conducted on the income of the Szczecin City Commune it should be stated that:

1. In the years 2017-2019, the budgetary income of the commune had a growing tendency, and its value was, respectively: PLN 2,157 million, PLN 2,289 million and PLN 2,639 million.

2. The structure of the commune's income in the analyzed period shows a stable tendency and did not undergo major changes.

3. The dominant item in the category of current income was the share in the income tax from natural persons and legal persons (share at an average level of approximately $28 \%)$.

4. The share of income from real estate management in total income was on average 17.44\% (value approximately PLN 410 million).

5. The most profitable item in real estate management, constituting approximately $60 \%$ of this income, was income from real estate tax (share in total income - approximately $10 \%)$.

The conducted research has shown that the real estate resource is an important source of income for the commune, and the most important is the real estate tax. The budget revenues from this source amounted on average to over PLN 240 million. 


\section{References}

1. Cymerman R., Filipiak-Kowszyk, D. (2015). Property valuation. Gdańsk: Publishing House of the Polish Internet Geodetic "Informator".

2. Cymermann, J. (2013). Local policy of real estate management in creating the value of real estate. Scientific Papers of the University of Economics in Katowice.

3. Gatnar, E., Walesiak, M. (2004). Methods of statistical multidimensional analysis in marketing research. Publisher of the University of Economics in Wroclaw.

4. Grabiński, T., Wydymus, S., Zelias, A. (2015). Methods of forecasting social and economic development. Warsaw: PWE.

5. Hanusz, A., Niezgoda, A., Czerski, P. (2006). Municipal budget revenue. Warszawa: Wolters Kluwer.

6. Kaganova, O., Nayyar-Stone, R. (2000). Municipal Real Property Asset Management. An Overview of World Experience, Trends and Financial Implications. Journal of Real Estate Portfolio Management, Vol. 6, No. 4.

7. Kokot, S. (2018). Municipal real estate management - discussion of selected problems. World of Real Estate, no. 7.

8. Lachiewicz, W. (2001). Changes in budgetary classification. Warszawa: C.H. Beck.

9. Leach, B., Ferreira, F., Winkler, H., Zolt, E.M. (2013). The Effect of Rising Income Inequality on Taxation and Public Expenditures: Evidence from U.S. Municipalities and School Districts, 1970-2000. Review of Economics and Statistics, Vol. 95, Iss. 4.

10. Marona, B., Van den Beemt-Tjeerdsma, A. (2018). Impact of Public Management Approaches on Municipal Real Estate Management in Poland and The Netherlands. Sustainability, no. 10(11).

11. Nowak, E. (1990). Taxonomic methods in classification of socio-economic objects. Warsaw: PWE.

12. Oclesa, M. (2016). Managing local taxes in the municipality using the example of property tax. Scientific Journals of the Czestochowa University of Technology "Management", Nr 24, t. 1 .

13. Report on the implementation of the budget of the Szczecin Municipality for 2017, 2018, 2019. www.bip.um.szczecin, 15.04.2020.

14. Simons, R. (1993). Public Real Estate Management-Adapting Corporate Practice to the Public Sector: The Experience in Cleveland. Journal of Real Estate Research, Vol. 8, No. 4.

15. Wiśniewski, R. (ed.) (2008). Gospodarowanie gminnymi zasobami nieruchomości. Olsztyn: Uniwersytet Warmińsko-Mazurski.

16. Źróbek, R. (2004). Real estates and their resources as the subject of the description and analyses. Acta Scientiarum Polonorum. Administratio Locorum, no. 3(1). 